\title{
Ética em autoria de trabalhos científicos
}

\section{Ethical considerations about authorship of scientific papers}

\author{
Sigmar de Mello Rode* \\ Bruno das Neves Cavalcanti**
}

\begin{abstract}
RESUMO: O texto alerta para a consciência da relação ética da produção intelectual no que refere a quantidade, qualidade, autoria e publicação. Reafirma a importância da questão ética do gerenciamento de grupos de trabalho e a efetiva participação no desenvolvimento do projeto experimental.
\end{abstract}

DESCRITORES: Pesquisa; Ética.

\begin{abstract}
This article stresses the importance of ethical relations involved in intellectual production, particularly as regards quantity, quality, authorship and publication. It reaffirms the importance of ethics while managing workgroups, and the effective participation in the development of experimental projects.

DESCRIPTORS: Research; Ethics.
\end{abstract}

Todo trabalho científico consome, em maior ou menor grau, tempo e dedicação de pesquisadores, consumo de material e uso de estruturas, na maioria das vezes universitárias no caso da Odontologia. No entanto, apesar da facilidade em elaborar, desenvolver e analisar pesquisas, muitas vezes nos deparamos com algumas questões relacionadas à definição da autoria dos trabalhos.

Mas essas questões poderiam ser mais facilmente respondidas se houvesse um treinamento especial aos autores, particularmente em seus cursos de pós-graduação, quanto a essa área bastante discutida na produção científica. Para se ter uma idéia, há legislação vigente e regras bem definidas por instituições sólidas que balizam com muita propriedade não só a definição de quem é autor, mas também a seqüência com que estes devem aparecer nas citações. Segundo as normas de Vancouver ${ }^{2}$, alguns princípios simples devem ser seguidos facilitando a vida do leitor, incluindo várias guias para os autores de trabalhos científicos. Entre as guias, encontra-se o fato de que os leitores de um trabalho científico têm o direito de acreditar que o que estão lendo é original, ou seja, a tão falada redundância em publicações deve ser evitada; forma de organização dos originais e principalmente, normas para qualificar uma pessoa como autor. Estas últimas podem ser resumidas da seguinte forma:
1. Contribuição substancial à concepção e ao desenho do trabalho científico, aquisição, interpretação e análise dos dados.

2. Redação e revisão crítica do trabalho, com real contribuição intelectual ao seu conteúdo.

3. Aprovação final do conteúdo a ser publicado.

4. As três primeiras condições devem ser atendidas por todos os autores, sendo que coleta de dados, coleta de fundos e supervisão (chefia) de grupo de pesquisa não são fatores que tornam uma pessoa autora de trabalho.

5. Os autores, se necessário, deverão justificar sua participação no trabalho científico, e o periódico deverá publicar essas atuações.

6. Todos aqueles que não se qualificam como autores deverão ser citados nos agradecimentos, incluindo sua participação no trabalho (tradução, aquisição de fundos, análises técnicas, empréstimo de material, entre outras).

7. Trabalhos multicentro possuem muitos autores pois cada grupo realiza uma parte do trabalho. Mesmo assim todos os participantes de um determinado grupo devem preencher os requisitos citados acima.

8. A ordem dos autores na citação deve ser feita de comum acordo entre todos os autores sendo o primeiro o mais relevante e o último o coordenador do projeto (sênior). Os autores intermediá-

\footnotetext{
* Livre-Docente em Odontologia, Coordenador do Curso de Odontologia da Universidade Ibirapuera, Professor Adjunto da Faculdade de Odontologia de São José dos Campos da Universidade Estadual Paulista, Ex-presidente da Sociedade Brasileira de Pesquisa Odontológica, gestão 1999-2000.

** Professor Assistente do Curso de Odontologia da Universidade Ibirapuera.
} 
rios podem ser citados em ordem de contribuição para o trabalho final.

Assim, fica patente que indivíduos com função pura e simplesmente técnica num trabalho (por exemplo, análise estatística, empréstimo de equipamento, operação de instrumento) não necessariamente devem ser considerados autores, uma vez que para isso, devem participar do planejamento, execução, interpretação e revisão do trabalho, sem no entanto deixarem de merecerem agradecimento, seção de trabalhos científicos que deve ser valorizada. Mas se um estatístico, por exemplo, ajuda a conceber o método, analisa e interpreta os resultados e participa na redação final com suas informações técnicas, já é configurado como autor. Em algumas instituições inclusive há a discussão sobre a presença de orientadores como autores, uma vez que muitos estudantes desenvolvem seus trabalhos sozinhos.

Para alguns, pela nossa cultura, a definição dos autores e da ordem com que aparecem nas referências pode ser definida por ascendência ou gratidão, que por si só não são fatores para se registrar alguém não participante do trabalho como autor. Infelizmente, particularmente pelo primeiro motivo citado, é muito comum ouvir-se relatos de pressões por parte de coordenadores, professores e orientadores, obrigando os subordinados, na maioria das vezes alunos, a citarem o nome de pessoas que muitas vezes nem sabem de que se trata o artigo a ser publicado. Para isto, vale lembrar que essas questões são contempladas pelo código de ética em Odontologia $^{1}$ no seu capítulo XIII, seção III:

Art. $34^{\circ}$. Constitui infração ética:

I - aproveitar-se de posição hierárquica para fazer constar seu nome na co-autoria de obra científica;

II - apresentar como sua, no todo ou em parte, obra científica de outrem, ainda que não publicada;

III - publicar, sem autorização, elemento que identifique o paciente;

IV - utilizar-se, sem referência ao autor ou sem sua autorização expressa, de dados, informações ou opiniões coletadas em partes publicadas ou não de sua obra;
V - falsear dados estatísticos ou deturpar sua interpretação.

Obviamente essas infrações são passiveis de punição que vai desde advertência até suspensão do direito profissional. Assim, uma questão bastante simples que é "põe o nome no trabalho", pode se transformar num problema sério que afeta a carreira do infrator.

Também deve-se levantar a questão ética pessoal, que apesar de não punir legalmente os infratores, pode provocar situações de ridículo. Muitos confundem a formação de grupos de pesquisa, fato desejado para se trabalhar em direção de um objetivo, com fábricas de trabalho, onde cada um faz um e prestigia os outros do grupo. Isso realmente multiplica a produção científica de cada um, já que no período suficiente para se realizar um trabalho, na verdade se publicam vários, que muitas vezes nem permitem a presença de mais de um ou dois autores (revisões de literatura por exemplo). Vale ressaltar que muitos periódicos importantes, ou seja, com índice de impacto, aceitam até quatro autores. No caso de mais de quatro, os outros devem ser justificados com descrição da participação na pesquisa. Obviamente isso não vale para trabalhos multicentro ou grandes projetos, como o Genoma por exemplo, onde pesquisadores de todo o mundo trabalham em prol de um resultado. Outra situação delicada é a de que para atender a requisitos de avaliações institucionais, muitas vezes quantitativas e não qualitativas, verifica-se pesquisadores com produção de mais de 2 trabalhos por mês (vinte, trinta trabalhos por ano), o que certamente denota a não-participação ou participação superficial na maioria dos projetos. Claro que não há um número ideal já que cada área tem exigências diferentes quanto a tempo para a realização de uma pesquisa, mas bom senso e no mínimo conhecimento de trabalhos que têm o seu nome é essencial.

Finalmente, cabe aos pesquisadores tomarem consciência de que cada vez mais a qualidade será sobreposta à quantidade, onde uma produção científica de $\mathrm{x}$ trabalhos em revistas bem conceituadas vale mais que y trabalhos em revistas locais e sem política editorial. Com certeza, mais do que legislações e/ou regulamentações vigentes, a consciência de cada um tem o papel decisivo na formação dos novos pesquisadores e na solidificação dos conhecimentos obtidos com a pesquisa. 
Rode S de M, Cavalcanti B das N. Ética em autoria de trabalhos científicos. Pesqui Odontol Bras 2003;17(Supl 1):65-6.

\section{REFERÊNCIAS}

1. Conselho Federal de Odontologia. Código de ética odontológica, 1998. 20p.

2. International Committee of Medical Journals Editors. Uniform requirements for manuscripts submitted to biomedical journals. Ann Inter Med 1997; 126:36-47. 